\title{
SOLAR ELECTRIC WHEELCHAIR WITH A FOLDABLE PANEL
}

\author{
Jainam J. Sanghvi' ${ }^{1}$, Maulik Y. Shah ${ }^{2}$, Jay K. Fofaria ${ }^{3}$ \\ ${ }^{1}$ Student, Department of Mechanical Engineering, A. D. Patel Institute of Technology, Gujarat, India. \\ ${ }^{2}$ Student, Department of Mechanical Engineering, A. D. Patel Institute of Technology, Gujarat, India. \\ ${ }^{3}$ Student, Department of Mechanical Engineering, A. D. Patel Institute of Technology, Gujarat, India.
}

Article DOI: $\underline{\text { https://doi.org/10.36713/epra8021 }}$

DOI No: 10.36713/epra8021

\begin{abstract}
For physically challenged individuals the most basic expression of freedom would be the ability to be mobile. Modern medical science being highly advanced designed a device of help for physically challenged individuals, called the wheelchair. The market provides a vast assortment of options in a wheelchair to fulfill the desired need and requirements of the consumer. To make the system energy efficient we have designed a solar wheelchair in which solar power is used. This keen wheelchair is additionally fitted with a leg guard for the safety of the legs. In addition, we have added a mechanism that allows our solar panel to fold and settle at a safe place, or in other terms, Solar Wheelchair with a foldable panel. All our effort has been in the direction, to make this solar-induced wheelchair at an affordable cost along with having an optimal utilization in the external as well as the internal environment.
\end{abstract}

KEYWORDS: Assistive device, Electric mode, Foldable solar panel, Solar Powered Wheelchair.

\section{INTRODUCTION}

As we all are aware that with respect to advancement in technology, wheelchairs have been modified such as voice modulation, automatic guidance, automatic joystick control, gesture controls, and a lot more. Our wheelchair is an Automatic Solar Wheelchair and as a part of innovation, we have added different features to it.

Many different kinds of wheelchairs have been previously designed; also, different solar wheelchairs have been designed. However, none thinking about the safety of one of the most important components, solar panels. We have designed a Solar Wheelchair by adding a foldable mechanism in the solar panel for its safety and a leg guard for the betterment of the driver. In addition, the wheelchair will be completely automatic and guided by a joystick.

\section{WHEELCHAIR DESIGNING}

The advancement \& creativity in science, led to the development of ample solutions in response to the problem of mobility with a variety of wheelchairs that can mount through the stairs, advance rough roads, follow local commands, or maybe respond to human thoughts as well. Usually, people demand indoor or outdoor surfaces that provide a comfortable $\&$ smooth experience along with reducing the amount of human labor for the physically disabled ones. Things ease-out, for handicaps if the user can see where he/she is going \& operate his/her joystick as well as control \& maneuver his/her chair with a few buttons easily. The operational power of solar the wheelchair is gained from sunlight, which is then stored to be utilized in times of need. 


\section{SJIF Impact Factor 2021: 8.013| ISI I.F.Value:1.241| Journal DOI: 10.36713/epra2016 \\ ISSN: 2455-7838(Online) EPRA International Journal of Research and Development (IJRD) \\ Volume: 6 | Issue: 8 | August 2021 \\ - Peer Reviewed Journal}

\section{SOLAR WHEELCHAIR}

Energy acts as the source of power to conduct life activities, the sources of which are depleting exponentially, that enforced mankind to discover \& increase the dependency upon inexhaustible resources, to curb the demands. Sunlight, amongst all the inexhaustible resources is plenty, eco-friendly and emission-free source. Therefore, it has been focused upon by the entire world to have its optimum usage for technical purposes. An electrically induced wheelchair is set in motion with the help of an electric motor rather than human effort. The difference between electrically \& manually induced wheelchairs lie in the former being four-wheeled \& non-foldable, whereas the latter is equipped with a system that provides auxiliary electrical power, which can be attached to the manually propelled wheels or integrated beneath the wheelchair. The electrical motors gain intensity through rechargeable batteries that are 4 or 5 amp deep cycled.

\section{EXPERIMENTAL SECTION}

The different components of our Solar Wheelchair are:

Frame, seat, armrest, leg rest, wheels, caster wheels, solar panel, solar battery charger, joystick, steering mechanism, indicators, DC motors, batteries, and support stands.

\section{A. $\quad$ Solar Panels}

The photovoltaic solar panels are the bundle of solar cells that are interconnected to form an assembly. The installation of a photovoltaic panel involves a lineup of solar panels, an inverter, batteries, and an interconnected network of wires. The panel contains 36 cells, 65 x 39 in, and a basic circuit voltage of $\mathrm{Voc}=22 \mathrm{~V}$. Somewhere between 12 $\& 14$ volts of working voltage. The area of $2535 \mathrm{in}^{2}$ is covered by the panels in total. All the cells offer around $15 \%$ efficacy. Considering the conditions to be appropriate $\&$ ideal, the power generated all to the critical calculation shall be $100 \mathrm{w}$. The solar wheelchair operates in 2 ways exposing \& charging it through sunlight and storing the energy to be utilized when in need. In case the stored solar energy is deployed, the user can change it with the help of a wall outlet changer.

\section{DPECIFICATION OF SOLAR MODULE:}

- $\quad$ Peak Power Output (P max, Watt $)=100$

- $\quad$ Current at P $\max (\mathrm{I} \max , \mathrm{Amp})=5.5$
- $\quad$ Voltage at P $\max (\mathrm{V} \max$, Volt $)=18.2$

- $\quad$ Short Circuit Current (I sc, Amp) $=5.92$

- $\quad$ Open Circuit Voltage (Voc, Volt) $=22$

- $\quad$ Dimensions (in inches) $=65 \times 39$

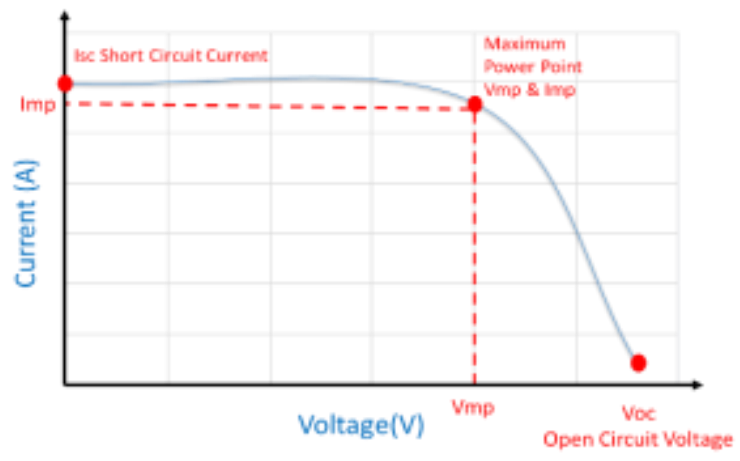

Fig I Voltage vs Current graph of solar panel

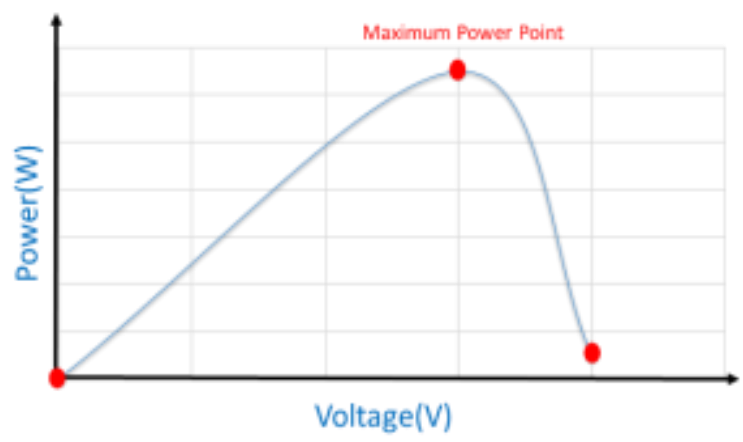

Fig II Voltage vs Power graph of solar panel

\section{B. $\quad$ Frame}

The frame acts as the selection of the solar wheelchair, which carries the complete weight of the user. The frame is the center where all the other parts are attached with the help of nut bolts or brackets. The frame is designed from iron, chrome, or steel square beams of diameter $35 \mathrm{~mm}$. The beams of different lengths are placed and soldered as an arc that aids it makes it capable to beam the weight and decrease the vibrations when in motion. The peak is set as $105 \mathrm{~cm}$, the width is $57 \mathrm{~cm}$ and the seating is $46 \times 48 \mathrm{~cm}^{2}$. The detailed planning \& designing of the wheelchair is done in such a way that the assemblies are arranged on both sides of the wheelchair, one per armrest. The solar panel deployment is regulated through a pivoting bracket, which rotates with the help of actuators that makes the panels emerge from the rear to front. 


\section{SJIF Impact Factor 2021: 8.013| ISI I.F.Value:1.241| Journal DOI: 10.36713/epra2016 ISSN: 2455-7838(Online) EPRA International Journal of Research and Development (IJRD)}

\section{Seat}

Umpteen number of options are available in regards to the size \& the luxury of the seat, but the one that maintains the weight of chair within a range of $25 \mathrm{~kg}$ suits the best. The seat size is to be managed according to the frame dimensions. Hooking towards the comfort of the chair, the preferential choice would be the one with a good headrest and arm support.

\section{Wheels}

The wheel assembly consists of a wheel hub, DC motor, and bolt $\&$ nuts, which couples the wheels to the motor shaft. The electrical motor is attached to the wheel hub. Hub motor is equipped with electromagnetic pads that make the motor windings steady. The outer motor obeys those wheels that turn the attached wheel. The best part about this design is that there is no need for extra transmission, which expands the efficiency of the drive system. The wheels of about $50 \mathrm{~cm}$ diameter and designed from aluminum or magnesium alloys have been used.

\section{E. Caster}

Caster is the small single, double, or compound wheels that are coupled at the bottom surface of a bigger object to help it maneuver. On this wheelchair, the caster is attached to the bottom surface of the seat that aides it to circulate around its axis which is horizontal, providing comfort to the user. Variations in caster are subjected to materials used for its manufacturing like rubber, aluminum, nylon, or chrome steel. These casters are commonly used in devices like carts available in malls and chairs available in offices. The diameter of the caster wheels used here is $15 \mathrm{~cm}$. Caster wheels can move freely over smooth \& flat surfaces.

\section{F. Battery Charger}

The amount of energy received through sunlight is uneven. The output from a solar PV module mounted on a structure depends, among others, on the $0^{\circ}$ angle at which the irradiations reach the module surface. To make the optimal use of sunlight the solar charge controllers are designed to extract the most amount of power available from the solar array and deposit it within the battery. These charge controllers are important to safeguard the PV battery investment.

\section{G. DC Motors}

The wheels will be operated with the help of two DC motors with a power of $24 \mathrm{~V}$ and restrained in a way that provides safety with the max speed of 6-8 miles/hr. Batteries will operate the motors.

\section{H. Battery}

The power generated from the solar panel needs to be stored which will be used to run the DC motors. Energy generated from the solar panel is stored in a battery, which is controlled by a solar battery charger. Then this power is used to run the motor. The battery we have used is a lead-acid battery of 12 $\mathrm{V}, 100 \mathrm{AH}$.

\section{Joystick}

To move a wheelchair automatically joystick is required. With the proper setup of the steering mechanism and with joystick it will direct motors and move the wheelchair forward, backward, left, or right.

\section{J. Steering mechanism}

The innovation \& designing of the solar-induced wheelchair is done in a way that it gains maximum power from an electric motor and not manually. At aids comfort to the patient of traditional as well as fatigued or cardiovascular impairments. Constant efforts in making the wheelchair more comfortable have presented the consumers with a variegated option such as, wheelchair with wheels \& nonfoldable or foldable and some that can temporarily dismantle for transit. Manual wheelchairs are equipped with a system that provides auxiliary electrical power with which it can take one of the above forms. Since it is equipped with handpropelled wheels the application of force on such aims is enlarged by the drive system, which transmits the driving force to most wheels either through a friction drive system or through an auxiliary drive wheel.

\section{K. Microcontroller}

The microcontroller is known as the little computer. They are drafted with ingrained applications and utilized in devices that are automatically controlled like implantable medical devices, power tools, or remote systems.

When the operator sends a signal from the joystick to take a turn, the microcontroller receives a signal and sends it to H-bridge to control the movement of wheels.

PIC16F877A is the microcontroller utilized in wheelchair circuit. Which is an automatic cheaper reliable and expandable system. 


\section{EPRA International Journal of Research and Development (IJRD)}

Volume: 6 | Issue: 8 | August 2021

- Peer Reviewed Journal

PIC16F877A features an 8-bit PIC CPU, 256 bytes data EEPROM, with operating voltage of 2 to $5.5 \mathrm{~V}$.

\section{L. $\quad H$-Bridge}

For the voltage that is supplied across the weight in all directions, H-bridge is necessary as a communicator mediating the programmed circuit \& the physical work done. H-bridge gives binary commands that set high-power actuators in action. The prime function of the H-bridge is to manage the rotational direction of the DC motor, which means the movement of the wheelchair in our case.

Thus, the wheelchair circuit is equipped with an $\mathrm{H}$ bridge made of four switches.
Table- I Direction control table

\begin{tabular}{|c|c|c|}
\hline $\begin{array}{c}\text { Joystick } \\
\text { movement }\end{array}$ & DC motor (left) & DC motor (right) \\
\hline & $\begin{array}{l}\text { Displace } \\
\text { backward }\end{array}$ & Displace forward \\
\hline & $\begin{array}{l}\text { Displace } \\
\text { forward }\end{array}$ & $\begin{array}{l}\text { Displace } \\
\text { backward }\end{array}$ \\
\hline & $\begin{array}{l}\text { Displace } \\
\text { forward }\end{array}$ & Displace forward \\
\hline & $\begin{array}{l}\text { Displace } \\
\text { backward }\end{array}$ & $\begin{array}{l}\text { Displace } \\
\text { backward }\end{array}$ \\
\hline
\end{tabular}

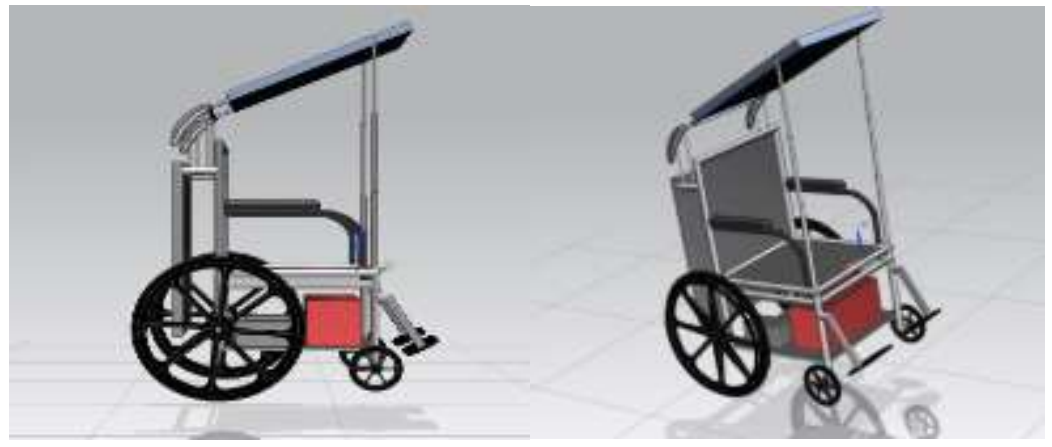

Fig I \& II Proposed design

\section{CALCULATIONS}

A. Rpm

Taking Maximum speed of wheelchair $\mathrm{V}=8$ $\mathrm{km} / \mathrm{hr}$.

RPM of shaft wheel (let say N).

$>\quad \mathrm{V}=\pi * \mathrm{D} * \mathrm{~N} / 60$

- $\quad \mathrm{V}=$ Speed of wheel chair $=8 \mathrm{~km} / \mathrm{hr}$

- $\quad \mathrm{Pi}=3.14$

- $\mathrm{D}=$ Diameter of wheel $=0.50 \mathrm{~m}$

- $\quad \mathrm{N}=\mathrm{Rpm}$ of wheel

$\mathrm{V}=\pi * \mathrm{D} * \mathrm{~N} / 60$

$8 * 1000 / 60 \times 60=(3.14 \times 0.50 \times \mathrm{N}) / 60$

$\mathrm{RPM}=\mathrm{N}=84.9=85$ (approx.)

\section{B. Weight}

If total weight $(\mathrm{W})=120 \mathrm{~kg}$ (Assume). Person (P) $=80 \mathrm{~kg}$, Weight of the system $(\mathrm{S})=40 \mathrm{~kg}$. $>\quad$ Weight (on each wheel) $=\mathrm{m} \times \mathrm{g}$

- $\quad \mathrm{m}=$ Mass on one wheel

- $\mathrm{g}=$ Gravity (9.81)

Weight $=\mathrm{m} \times \mathrm{g}$

Weight $=60 \times 9.81=588.6$ Newton

$$
\begin{array}{ll}
\text { C. } & \text { Torque } \\
> & \mathrm{T}=\mathrm{F}^{*} \mathrm{r} \\
\bullet & \mathrm{T}=\text { Torque } \\
- & \mathrm{F}=\text { Force } \\
- & \mathrm{r}=\text { Radius }
\end{array}
$$

Torque $=588.6 \times 0.05(\mathrm{D}=10 \mathrm{~cm}, \mathrm{r}=5 \mathrm{~cm})$

Torque $=29.43 \mathrm{Nm}$

D. Power

$>\quad$ Power $=2 * \mathrm{pi}^{*} \mathrm{~N} * \mathrm{~T} / 60$

Power $=2 \times 3.14 \times \mathrm{N} \times \mathrm{T} / 60$

Power $=2 \times 3.14 \times 85 \times 24.943 / 60$ 


\section{EPRA International Journal of Research and Development (IJRD) \\ Volume: 6 | Issue: 8 | August 2021

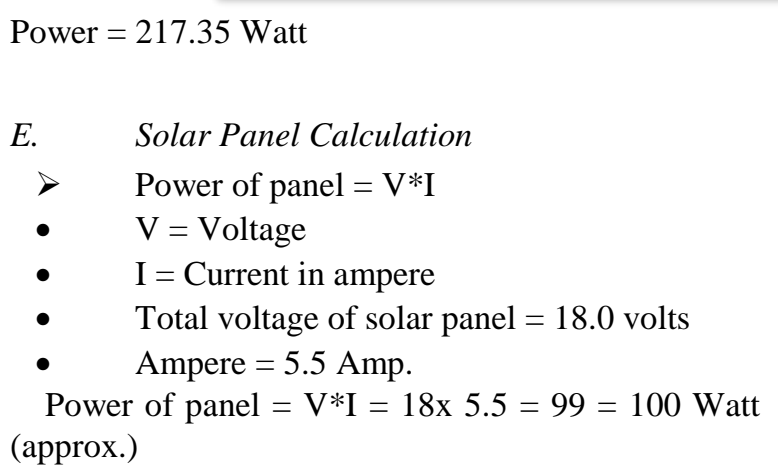

\section{FOLDING MECHANISM}

As shown in the above pictures, we have added a mechanism for the folding of solar panels. As we know, solar panels are very costly and harm to the panel cannot be afforded. However, while the panel is open or in its normal position, birds or other varying conditions can harm it. Keeping this idea in mind, we started research over it and developed a machine that can fold the panel and keep it in a safe place.

Support for panel after folding is added, which will be of sponge. It helps absorb shocks and keep the solar panel intact. The mechanism added is not much costly and can be adjusted in a small amount. The mechanism is easy and simple as shown in Figures I, II, III, IV. While manual driving or nighttime, the panel is inactive. At this time, the panel is not needed, and

$$
\begin{array}{ll}
\text { F. } & \text { Traction Force } \\
\text { - } & \mathrm{F}(\text { one wheel })=\mu \mathrm{t} \mathrm{W} \\
\text { - } & \mathrm{F}=\text { Traction force }(\mathrm{N}) \\
\text { - } & \mathrm{W}=\text { Traction or coefficient of friction } \\
\text { - } & \mathrm{m}=\text { Mass on the wheel }(\mathrm{kg}) \\
\text { - } \quad \mathrm{ag}=\text { Acceleration of gravity }(9.81 \mathrm{~m} / \mathrm{s} 2) \\
\mathrm{F}(\text { one wheel })=\mu \mathrm{t} \mathrm{W} \\
\mathrm{F}=(\mu \mathrm{t} \mathrm{mag}) / 4 \\
\mathrm{~F}=(0.9 \times 120 \times 9.81) / 4 \\
\mathrm{~F}=1059.48 / 4 \\
\mathrm{~F}=264.87 \mathrm{~N}
\end{array}
$$

$\mathrm{F}($ both wheels $)=2(264.87)=529.74 \mathrm{~N}$

not having it in its normal position is a better option. The panel can be easily cleaned after folding, thus increasing its efficiency and lifetime.

\section{A. Working}

It is having a very simple and easy mechanism and does not need any expertise. It is a long-lasting mechanism and needs normal and small maintenance like cleaning and oiling.

When a Solar panel is not in use, slowly unlock the panel from the support stand. By applying normal force fold the panel in the upward direction and slide it from grooves. After it sliding, rotate and fold the solar panel into its carrier ensuring the safety of the panel.

The support stand is also foldable. Push the topmost layer into the second carefully. Repeat the same for the third one and thus the stand will go inside.

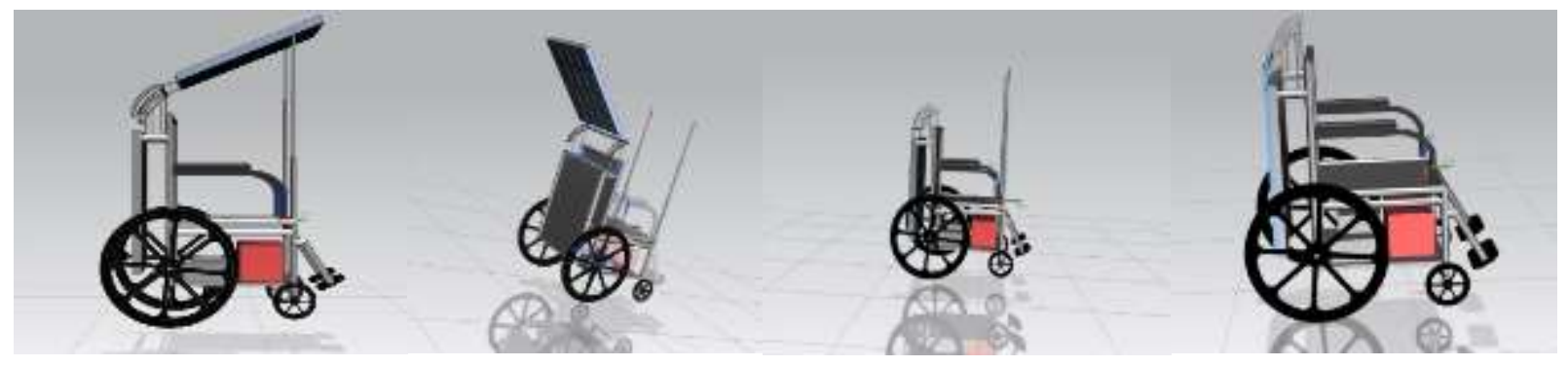

Fig I, II, III and IV Folding Mechanism 


\section{SJIF Impact Factor 2021: 8.013| ISI I.F.Value:1.241| Journal DOI: 10.36713/epra2016 ISSN: 2455-7838(Online) EPRA International Journal of Research and Development (IJRD)

\author{
Volume: 6 | Issue: 8 | August 2021
}

\author{
- Peer Reviewed Journal
}

\section{CONCLUSION}

The solar electric wheelchair with a foldable panel provides freedom to physically challenged people. The solar panel allows users to store solar energy in the battery during the daytime and use it for their mobility. With the help of all the components like motor, steering mechanism, joystick, etc. allows sufficient mobility to the users. Separate motors are used to take a turn on a straight path. The proposed design is the extension of previously made Solar Wheelchairs with certain advancements and certain

\section{REFERENCE}

1. Shamim Kaiser, Zamshed Iqbal Chowdhury, Shamim Al Mamun, Amir Hussain, and Mufti Mahmud, "A Neuro-Fuzzy Control System Based on Feature Extraction of Surface Electromyogram Signal for Solar-Powered Wheelchair," Cogn Comput, vol. 8, no. 5, pp. 946-954, Oct. 2016, doi: 10.1007/s12559-0169398-4.

2. AKM Bahalul Haque, Shawan Shurid, Afsana Tasnim Juha, Md. Shadman Sadique, and Abu Sayem Mohammad Asaduzzaman, "A Novel Design of Gesture and Voice Controlled SolarPowered

3. Smart Wheel Chair with Obstacle Detection," in 2020 IEEE International Conference on Informatics, IoT, and Enabling Technologies (ICIoT), Feb. 2020, pp. 23-28. doi: 10.1109/ICIoT48696.2020.9089652.

4. Syed Nazmus Sakib, Syeda Puspita Mouri, Zannatul Ferdous, and M. Shamim Kaiser, "A study on low cost solar powered wheel chair for disabled people of Bangladesh," in 2015 18th International Conference on Computer and Information Technology (ICCIT), Dhaka, Bangladesh, Dec. 2015, pp. 27-31. doi: 10.1109/ICCITechn.2015.7488037

5. Chi-Sheng Chien, Tung-Yung Huang, Tze-Yuan Liao, Tsung-Yuan Kuo, and Tzer-Min Lee, "Design and development of solar powerassisted manual/electric wheelchair," J Rehabil Res Dev, vol. 51, no. 9, pp. 1411-1425, 2014, doi: 10.1682/JRRD.2013.11.0250.

6. Ali H A Alwaeli, "Electric-powered wheelchair with solar cell and single axis tracker," International Journal of Computation and Applied Sciences IJOCAAS, vol. 4, no. 2, p. 6, 2018.

7. Nida Riaz and Junaid Bin Aamir, "Electrical wheel chair with retractable solar panels," in 2014 International Conference on Energy Systems and Policies (ICESP), Islamabad, points at which they were lagging like efficiency, economy, design, etc.

Our solar electric wheelchair has a foldable solar panel that allows it to fold and settle at a safe place providing safety to the solar panel. The foldable panel can easily be cleaned after folding it, thus increasing its efficiency and lifetime. This solar wheelchair is economical and efficient. The prime benefit of our solar wheelchair is that, it provides safety to solar panels, and is eco as well as userfriendly in nature

Pakistan, Nov. 2014, pp. 1-6. doi: 10.1109/ICESP.2014.7346983.

8. VV Dighe, Sadaphal Avinash Bapusaheb, Shinde Ankita B., and Kurup Vidya V., "Self-Assisted Solar operated Wheelchair," IJARIIE, vol. 3, no. 1, p. 6, 2017.

9. P. Kishore, Manikandan Ananth, Sethu Chidambaram, B. Vivekanandan, and $N$. Ammasai Gounden, "Solar Based Hybrid Electric Powered Wheel Chair," in 2013 Texas Instruments India Educators' Conference, Bangalore, Apr. 2013, pp. 18-24. doi: 10.1109/TIIEC.2013.11.

10. Prof S.s.rashinkar, S. S. Lohar, A. L. Bhoi, P.V.GAVALI, and K. S. Ambekar, "SOLAR POWERED ELECTRIC WHEEL CHAIR," JournalNX, pp. 35-37, 2017.

11. A.H Aswathy et al., "Solar powered intelligent electric wheel chair with health monitoring system," in 2017 International Conference on Technological Advancements in Power and Energy ( TAP Energy), Kollam, Dec. 2017, pp. 1-5. doi: 10.1109/TAPENERGY.2017.8397319.

12. Neela Madheswari, S. Latha, and M. Iswarya, "Solar powered wheel chair with voice controller for physically challenged persons," in 2017 2nd International Conference on Communication and Electronics Systems (ICCES), Coimbatore, Oct. 2017, pp. 987-991. doi: 10.1109/CESYS.2017.8321229. 